\title{
EVALUATION OF FLUORIDE-RELEASING CAPACITY FROM POLYVINYL ALCOHOL POLYMER TAPE SUPPLEMENTED WITH NAF IN ORAL CAVITY
}

\author{
Ka-Young Lee, Sang-Ho Lee, Nan-Young Lee \\ Department of Pediatric Dentistry, College of Dentistry, Chosun University
}

\section{Abstract}

The purpose of this study is to investigate fluoride release in the oral cavity from polymer adhesive tape which is NaF coated PVA. 45 healthy adults were divided into 3 groups by the type of topical fluoride applied: 60 sec- $^{-}$

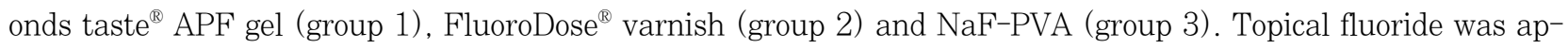
plied to the facial surface of maxillary 12 teeth and unstimulated whole saliva was collected to measure fluoride release after 1, 3, 6, 12, 24, and 48 hours. Fluoride-sensitive electrode was used for measuring the fluoride concentration in the saliva samples.

All three groups showed significantly higher value for fluoride concentration than the baseline after 1 and 3 hours $(p<0.05)$.

After 6 hours, group 3 showed significantly higher fluoride concentration than the baseline $(p<0.05)$ and also showed significantly higher value for fluoride concentration than group 1 and group 2 . Between group 1 and group 2, however, there was no significant difference statistically with respect to fluoride concentration value $(p>0.05)$.
\end{abstract}

Key words : Fluoride tape, Fluoride-ion concentration, Polyvinyl alcohol (PVA)

\section{I. 서 론}

치아우식증을 예방하기 위해서 불소는 다양한 적용방법을 통 해 널리 사용되어왔다. 불소에 의한 치아우식증 예방기전에 대 해서는 아직도 논란이 계속되고 있으나, 법랑질의 내산성 증가, 재광화의 촉진, 치면 세균막의 우식 유발능력의 감소 등이 일반 적으로 받아들여지고 있다 ${ }^{1)}$. 이와 같은 불소의 치아우식증 예방 기전이 효과적으로 적용되기 위해서는 치아주위의 액체 환경 속에서 불소가 일정한 농도로 유지되어야 하는데 ${ }^{2.3)}$, 여러 in vitro 연구들을 통해 불소의 치아우식증 예방 효과는 구강환경
에서 낮은 농도 $(>0.04 \mathrm{ppm})$ 의 불소가 지속적으로 존재하는 것 과 관련이 있다고 하였다 ${ }^{4-6)}$.

비자극성 타액 내 불소농도는 주어진 시간 동안 치면과 상호 작용이 가능한 aqueous phase의 불소의 양을 의미한다고 알려 져 있다 ${ }^{7)}$. 따라서 타액 내의 불소농도를 조사함으로써 간접적으 로 우식예방효과에 대한 정보를 얻을 수 있다.

불소의 국소적 공급방법은 자가 불소도포법과 전문가 불소도 포법으로 나뉜다. 전문가 불소도포는 치과진료실에서 비교적 고농도의 불소제제를 치면에 도포하는 방법으로, 사용하는 제 제로는 불소겔, 불소폼, 불소바니쉬를 들 수 있는데 이러한 불

\section{Corresponding author: Sang-Ho Lee}

Department of Pediatric Dentistry, College of Dentistry, Chosun University, 375 Seosuk-dong, Dong-gu, Gwangju, 501-825, Korea

Tel: +82-62-220-3860 / Fax: +82-62-225-8240 / E-mail: shclee@chosun.ac.kr

Received January 16, 2013 / Revised May 6, 2013 / Accepted May 8, 2013

※ This research was supported by Basic Science Research Program through the National Research Foundation of Korea (NRF) funded by the Ministry of Education, Science and Technology (2012-0569). 
소제제들은 도포시간 동안 섭취되는 불소로 인한 일시적인 오 심, 구토와 같은 불편감, 치은에 자극을 주거나 치아에 일시적 인 착색을 일으킬 수 있다는 점, 끈끈한 질감 등의 단점이 있다8).

근래에는 낮은 농도의 불소를 일정한 속도로 지속적으로 유 리시키기 위해 새로운 불소전달시스템에 대한 연구가 많이 진 행되어왔다. Toumba와 Curzon"은 불소를 결합시킨 완속유리 제제를 개발하여 구강 내에 부착하는 장치를 고안하였으며 Marini 등 ${ }^{10)}$ 은 하이드록시에틸 메타크릴레이트와 메틸 메타크 릴레이트 공중합체를 이용하여 최장 180 일 동안 불소를 유리할 수 있는 장치를 고안하였다. 그러나 이러한 완속유리제제의 문 제점은 용기의 부피로 인해 이물감이 크며 치아로부터 자주 탈 락이 된다는 것이다. 또한 불소농도를 조절하기 어려워 장기간 에 걸쳐 과량의 불소가 공급될 수 있다는 문제점이 있다. 따라 서 구강 내에서 불편감이 적고 불소를 더 효과적으로 적용할 수 있는 새로운 매개체 개발의 필요성이 대두되고 있다.

최근 인체에 무해하고 자극성이 없으며 생체 친화력이 좋은 고분자에 대한 연구가 활발히 진행 중인데, 고분자 중 친수성과 생분해성이 우수한 PVA (polyvinyl alcohol)이 약물의 제어방 출에 첨가되는 기저재로 알려져 있다. 이에 본 연구에서는 새로 운 불소전달체계의 일환으로 생체 안정성이 입증된 고분자제제 인 PVA로 얇은 박막을 제조하고 불화나트륨을 첨가하여 불소 를 함유한 고분자 접착 테이프를 개발, 제조하여 이의 구강 내 에서의 불소 유리 능력을 평가해보고자 하였다. 이를 위해 피실 험자의 구강 내에 불소 테이프 부착 후 시간 변화에 따른 비자 극성 타액 내 불소농도를 측정하고, 현재 전문가 불소도포로 임 상에서 많이 사용되고 있는 국소불소제제인 불소겔과 불소바니 쉬의 적용 후 비자극성 타액 내 불소농도와 비교, 평가하여 이 의 치아우식증 예방효과를 간접적으로 알아보고자 하였다.

\section{II. 연구 재료 및 방법}

\section{1. 연구 대상}

건강한 치열을 지니고 구강 위생 상태가 양호한 45명 (남성 30 명, 여성 15 명)을 연구 대상으로 하였다. 남성의 평균연령은 30.4 세였으며, 여성의 평균연령은 33.0세였다. 타액 분비에 영 향을 미칠 수 있는 전신 질환, 즉 두경부에 방사선치료를 받고 있거나 류마티스성관절염, 쇼그렌증후군, 유육종증 등과 같은 자가면역성질환, 당뇨(type I), 신경성식욕부진, 영양장애와 빈 번하게 단식을 반복하는 경우는 실험 대상에서 제외하였다. 또 한 지난 6 개월 동안 타액 분비에 영향을 준다고 알려진 약물, 예를 들어 항우울제, 이뇨제, 항히스타민제와 마취제 등이나 기 타의 구강건조증상을 치료하기 위해 약물을 복용한 사람들도 연구 대상에서 제외하였다. 그 외 비자극성 타액 분비율이 분당 $0.1 \mathrm{~mL}$ 이하인 경우는 연구 대상에서 제외하였다.

\section{2. 연구 재료}

본 연구에 사용한 불소를 함유한 고분자 접착 테이프 $\left(\mathrm{NaF}^{-}\right.$ PVA)는(Fig. 1), 기저제인 PVA와 PAA (polyacrylic acid)을 증류수에 용해시킨 후 가소제로 PEG (polyethylene glycol)을 첨가하여 $85^{\circ} \mathrm{C}$ 에서 2 시간 교반하였다. 그 후 $0.95 \mathrm{~g}$ 의 불화나 트륨을 첨가하고 동일한 교반과정을 거쳤다. 가교화 과정을 마 친 PVA 용액을 표면이 고른 유리판에 부은 후 작은 도구를 이 용해 균일한 두께를 $(20 \mu \mathrm{m})$ 만들었고 $60^{\circ} \mathrm{C}$ 에서 24 시간동안 건 조하였다(Fig. 2). 그리고 NaF-PVA 테이프의 불소 유리 능력 을 비교, 평가하기 위해 시판되고 있는 산성불화인삼염 겔 (1.23\% fluoride ion, 60seconds taste ${ }^{\circledR}$, Pascal Inc., USA) 과 불소바니쉬 ( $5 \% \mathrm{NaF}$, FluoroDose ${ }^{\circledR}$ Centrix Inc., USA) 를 대조군으로 선정하였다. 불소농도 측정을 위하여 불소이온 전극(Orion 9609, Thermo Scientific, USA)과 불소이온측정 기(Orion 4-star, Thermo Scientific, USA)를 사용하였다 (Fig. 3).

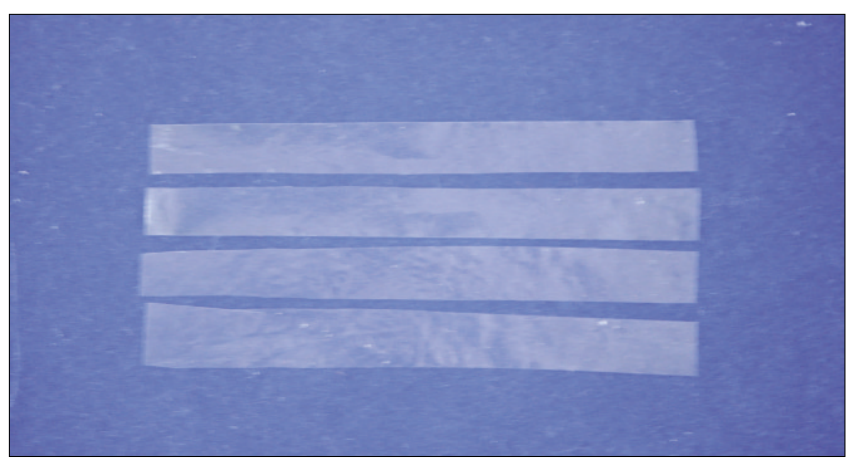

Fig. 1. NaF-PVA tape (Trial product), which is colorless and transparent.

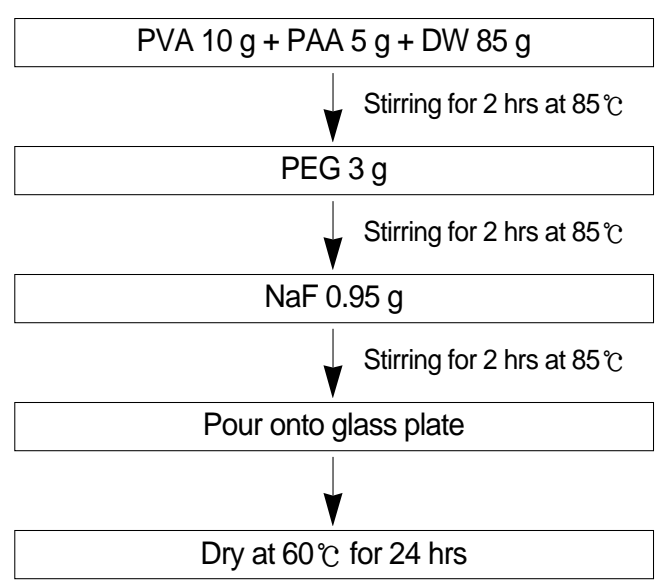

Fig. 2. NaF-PVA tape manufacturing process. PVA and PAA were added to distilled water and the mixture was stirred. PEG, as a plasticizer, and $\mathrm{NaF}$ were added progressively and stirred. The mixture was poured onto a glass plate, and spread to a uniform in width $(20 \mu \mathrm{m})$ using an applicator, and dried for 24 hours. 


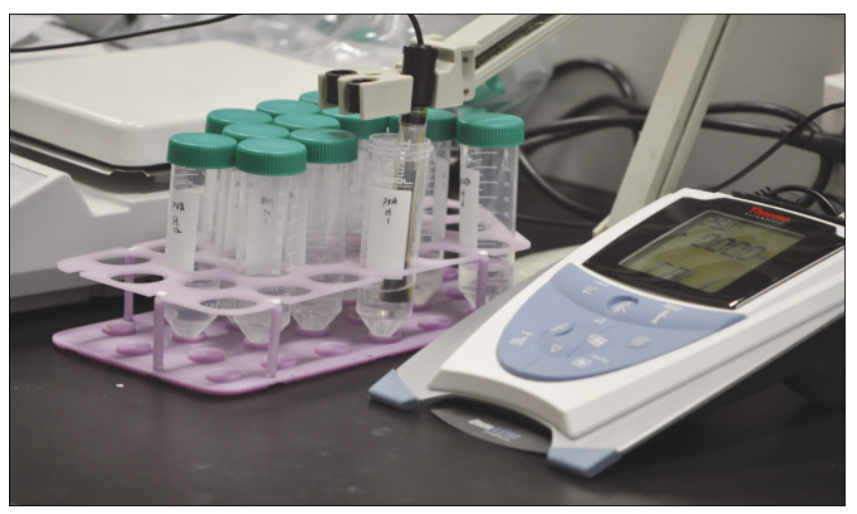

Fig. 3. Fluoride sensitive electrode (Orion 9609, Thermo Scientific, USA) and $\mathrm{pH} / \mathrm{ISE}$ meter (Orion 4 star, Thermo Scientific, USA) were used in the study.

\section{3. 연구 방법}

연구는 본 치의학전문대학원의 임상 연구 윤리 위원회 (Institutional Review Board, IRB)의 지침에 따라 수립하였 으며, 심의 절차 과정을 통과하였다(IRB번호 : $\mathrm{CDMDIRB-}$ 1218-93).

\section{1) 연구 전 준비}

연구 대상자들에게 연구 일주일 전부터 불소가 함유되지 않 은 동일한 치약(Wiconi, Shinwha, Korea)과 동일한 칫솔 (Oral-B vision, P\&G, China)을 사용하여 하루 3회 동일한 방법으로 칫솔질하도록 지시하였다. 또한 전 연구 기간 동안 불 소 함량이 높은 식품인 해산물, 어패류, 녹차, 광천수 또는 광천 수로 제조된 음료수 등의 섭취를 하지 않도록 사전에 교육을 실 시하였다. 피실험자들은 각 불소제제의 종류에 따라 무작위로 15명씩 세 그룹으로 나누었다.

2) 비자극성 타액 수집 방법 교육

모든 연구 대상자들에게 비자극성 타액 수집 방법을 교육시 켰다. 타액 채취 시 조용히 앉아 고개를 약간 숙이고 미리 준비 된 $15 \mathrm{~mL}$ 원심분리기 용기 (Centrifuge tube, SPL, Korea)에 2 분간 타액을 뱉도록 하였다. 타액을 모으는 동안 말을 하거나 혀로 구강조직을 자극하지 않도록 하였다. 실험 2 일 전부터는 동일한 시간에 타액을 수집하여 비자극성 타액분비율 $(\mathrm{mL} / \mathrm{min})$ 과 비자극성 타액 내 불소농도 $(\mathrm{ppm})$ 를 측정하였다. 타액을 수집하기 전에는 항상 동일한 칫솔과 치약을 사용하고 동일한 양의 수돗물로 세척하도록 하였다.

3) 불소도포

(1) 제 1 군 : 불소겔 군

불소도포 직전에 동일한 치약과 칫솔로 칫솔질 한 후, 상악 좌측 제 1 대구치부터 우측 제 1 대구치까지, 12 개 치아의 순면에
$1 \mathrm{~mL}$ 의 불소겔을 면봉을 이용하여 골고루 도포하였다. 도포하 는 동안에 삼키지 않도록 타액흡입기를 이용하여 흡입하였으 며, 1 분간의 도포 후 잔존하는 불소겔은 뱉어내도록 지시하였 다. 도포 후 1 시간 동안 양치와 음식물 섭취를 금지하였다. 실 험 후 1 시간, 3 시간, 6 시간, 12 시간, 24 시간, 48 시간 경과 후 에 비자극성 타액을 채취하였다. 실험 당일은 칫솔질을 금지하 였고, 다음날 아침부터 불소가 함유되지 않은 치약으로 칫솔질 하도록 하였다.

\section{(2) 제 2군 : 불소바니쉬 군}

불소도포 직전에 불소겔 군과 동일한 방법으로 칫솔질하고, $0.3 \mathrm{~mL}$ 의 불소바니쉬를 피실험자의 상악 12 개 치아 순면에 각 각 도포하였다. 제조사의 지시에 따라 도포 후 1 분간 압축공기 를 이용하여 건조하도록 하였다. 도포방법과 타액채취 방법 및 시간은 1 군과 동일하였다.

(3) 제 3군 : NaF-PVA 테이프 군

실험 직전에 1 군, 2 군과 동일한 방법으로 칫솔질하고 $1 \times$ $12 \mathrm{~cm}$ 크기의 NaF-PVA 테이프 1 매를 상악 12 개 치아 순면 에 접착하였다. 테이프 접착 이후 타액채취 방법과 시간은 1 군 과 동일하였다.

\section{4) 불소농도 측정}

모아진 타액 표본은 상온에서 보관하였으며, 표본의 $1 \mathrm{~mL}$ 를 15 분간 3,500 rpm으로 원심분리(GPR Centrifuge, $\left.\operatorname{Beckman}^{\circledR}, \mathrm{USA}\right)$ 하여 상층액 $0.5 \mathrm{~mL}$ 를 취하여 미리 준비한 $15 \mathrm{~mL}$ 용기에 담고, 탈 이온수 $(4.5 \mathrm{~mL})$ 와 혼합하여 10 배 희 석시켰다. 또한 이온세기를 일정하게 유지하고, $\mathrm{pH}$ 를 안정화시 키기 위해 TISAB II (Total Ionic Strength Adjuster Buffer II)을 타액 표본과 같은 양 $(5 \mathrm{~mL})$ 혼합하여, 최종 타액 표본을 만들었다. 그리고 불소이온전극의 보정을 위해 $10 \mathrm{ppm}$, $1 \mathrm{ppm}, 0.1 \mathrm{ppm}, 0.01 \mathrm{ppm}$ 의 불소표준용액 $(5 \mathrm{~mL})$ 을 준비 하였다. 타액 표본과 마찬가지로 불소 표준용액과 TISAB II을 1 : 1 의 부피비로 혼합하였다.

불소이온전극을 불소이온측정기에 연결하고 낮은 농도의 표 준용액부터 순서대로 보정하여 기준 값을 불소이온측정기에 입 력했다.

전극의 전위가 온도에 의해 변화되는 것을 방지하기 위하여 수집한 모든 타액 표본과 표준용액을 $25^{\circ} \mathrm{C}$ 의 동일한 온도에서 측정했다. 모든 표준용액 및 타액 표본은 자석교반기를 이용하 여 열을 가하지 않은 상태에서 균일하게 혼합되도록 하면서 이 온 농도를 측정하였다. 불소이온전극은 매 2 시간마다 다시 보 정하였다.

\section{5) 통계 분석}

불소농도 측정은 3 회씩 반복 측정하여 평균값을 택하였고 통 계 분석 프로그램인 SPSS/PC+ 17.0 을 이용하여 처리하였다. 불소제제 도포 전 농도와 불소제제 도포 후 비자극성 타액 내 
불소농도 사이의 유의차 검사로 Wilcoxon's signed-ranks test를 시행하였다. 불소도포 후 각 시간에 따른 군 간 타액 내 불소농도의 유의성 차이를 비교하기 위해 Kruscal Wallis test 를 시행하였으며 사후 검정으로 Mann-Whitney U test를 시 행하였다.

\section{III. 연구 성적}

\section{1. 연구 전 비자극성 타액분비율(Table 1)}

실험 전 2 일 동안 측정한 비자극성 타액분비율은 평균 0.851 $\pm 0.378 \mathrm{~mL} / \mathrm{min}$ 이었으며, 1 군에서 $0.817 \pm 0.321$ $\mathrm{mL} / \mathrm{min}, 2$ 군에서 $0.803 \pm 0.426 \mathrm{~mL} / \mathrm{min}$, 3군에서 0.933 $\pm 0.392 \mathrm{~mL} / \mathrm{min}$ 으로 각 군 간에 통계적 유의차는 없었다 $(p>0.05)$.

\section{2. 연구 전 비자극성 타액 내 초기 불소농도(Table 1)}

연구 전 비자극성 타액 내 초기 불소농도는 평균 $0.057 \pm$ $0.032 \mathrm{ppm}$ 이었으며 1군에서 $0.049 \pm 0.010 \mathrm{ppm}, 2$ 군에서 $0.067 \pm 0.046 \mathrm{ppm}, 3$ 군에서 $0.056 \pm 0.029 \mathrm{ppm}$ 으로 각 군 간에 통계적 유의차는 없었다 $(p>0.05)$.

Table 1. Salivary flow rate $(\mathrm{mL} / \mathrm{min})$ and fluoride concentration $(\mathrm{ppm})$ of unstimulated human mixed saliva at pre-experimental stage (Baseline)

\begin{tabular}{ccc}
\hline Group & $\begin{array}{c}\text { Salivary flow rate } \\
(\mathrm{mL} / \mathrm{min})\end{array}$ & $\begin{array}{c}\text { Fluoride concentration } \\
(\mathrm{ppm})\end{array}$ \\
\hline Group 1 & $0.817 \pm 0.321$ & $0.049 \pm 0.010$ \\
Group 2 & $0.803 \pm 0.426$ & $0.067 \pm 0.046$ \\
Group 3 & $0.933 \pm 0.392$ & $0.056 \pm 0.029$ \\
$p$ value & 0.428 & 0.536 \\
\hline
\end{tabular}

Kruscal Wallis test

$*$ : Significantly different between groups $(p<0.05)$
3. 불소제제 적용 후 타액 내 평균 불소농도 변화(Table 2, Fig. 4)

불소제제 도포 전 비자극성 타액 내 불소농도와 불소제제 도 포 후 시간의 경과에 따른 비자극성 타액 내 불소농도를 측정한 결과, 1 군과 2 군에서는 도포 후 3 시간까지 불소제제 도포 전 농 도보다 유의하게 높은 농도를 보였으며 $(p<0.05) 3$ 군에서는 도포 후 6시간까지 불소제제 도포 전 농도보다 유의하게 높은 농도를 보였다 $(p<0.05)$.

시간 경과에 따른 불소농도는 모든 군에서, 1시간부터 6시간 까지 점차 감소하는 양상을 보였는데, 1 군은 $14.692 \mathrm{ppm}$ 에서 $0.064 \mathrm{ppm}$ 으로, 2 군은 $16.356 \mathrm{ppm}$ 에서 $0.071 \mathrm{ppm}$ 으로, 3 군은 $16.625 \mathrm{ppm}$ 에서 $0.780 \mathrm{ppm}$ 으로 점차 감소했다. 그러 나 세 군 모두 12시간 이후부터는 $0.050 \sim 0.070 \mathrm{ppm}$ 으로 비 슷한 측정값을 보였다.

또한 Table 3와 Fig. 4에서 각 시간대별, 세 군 사이의 불소 농도 차이를 비교해 볼 수 있다. 불소제제 도포 1 시간 후, 3 군 (16.625 ppm)이 가장 높은 불소농도를 보이고, 2군(16.356 $\mathrm{ppm}), 1$ 군(14.692 ppm)의 순으로 분포를 보였으나, 통계검 사 결과 세 군 간 유의한 차이는 없었다 $(p>0.05)$. 도포 3시간 후에도 3 군 $(4.180 \mathrm{ppm})$ 이 가장 높은 타액 내 불소농도를 보였 고, 그 다음 2군(2.279 ppm), 1 군 $(1.880 \mathrm{ppm})$ 순으로 측정 되었다. 도포 6 시간 후에는 3 군 $(0.780 \mathrm{ppm})$ 이 가장 높은 불소 농도를 보였고, 2 군 $(0.071 \mathrm{ppm}), 1$ 군 $(0.064 \mathrm{ppm})$ 의 순으로 유의하게 높은 불소농도를 보였다 $(p<0.05) .12$ 시간부터 48 시간까지는 0.050 0.070 ppm으로 세 군이 모두 비슷한 농도 로 측정되었다.

불소제제 도포 후 각 시간대별로 측정된 불소농도 사이의 통 계적 유의성을 검사하기 위해 Kruscal Wallis test를 시행한 결 과 불소제제 도포 후 3시간과 6시간에서 세 그룹 간 통계적으로 유의한 차이를 보였고 $(p<0.05)$ (Table 3$)$, 구체적으로 어느 그룹 사이에서 어떠한 차이를 보이는지 알아보기 위해 사후검정 을 시행하였다. 도포 후 3시간에서는 각 그룹 간에 모두 유의한

Table 2. Fluoride concentration (ppm) of unstimulated human mixed saliva after different topical fluorides application

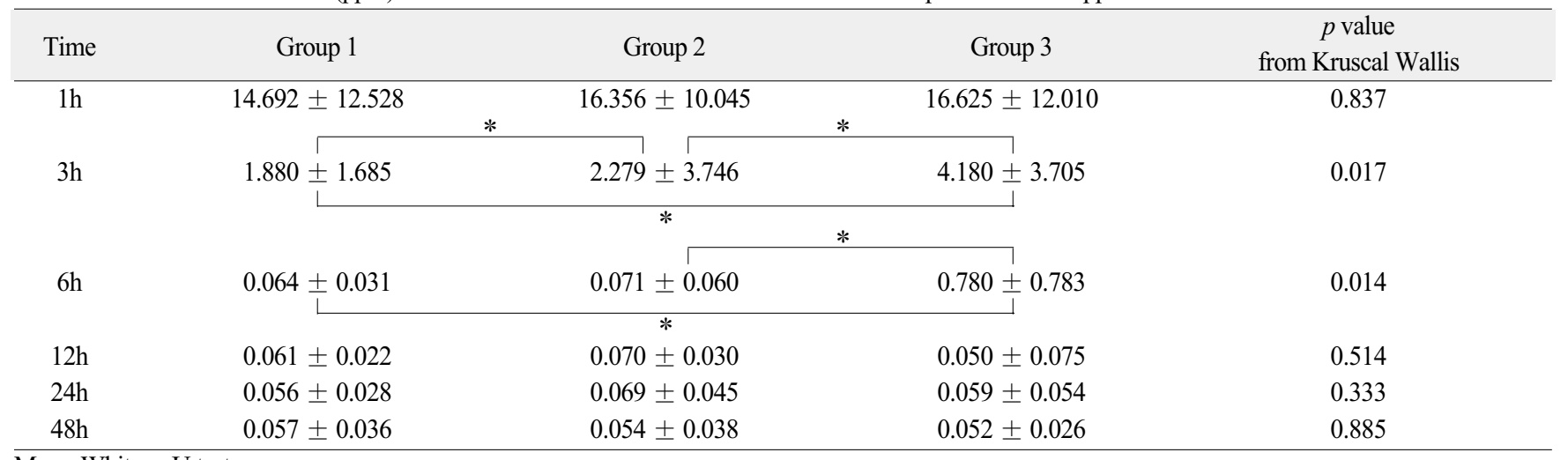


A

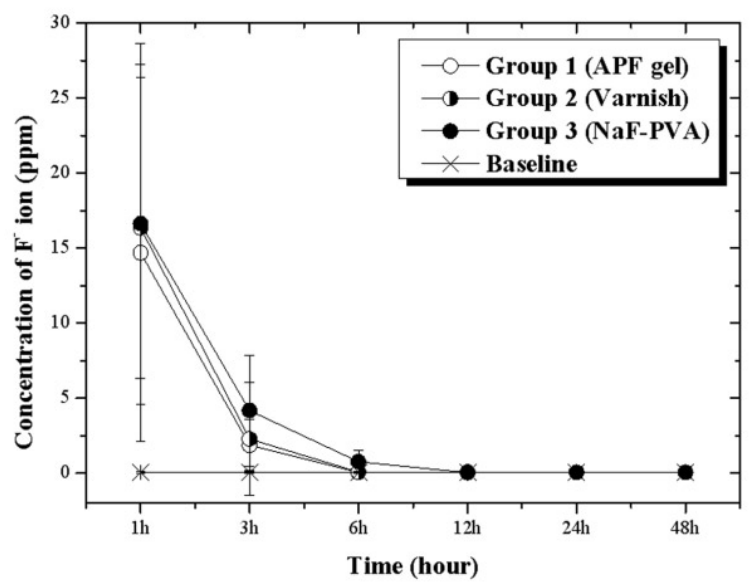

B

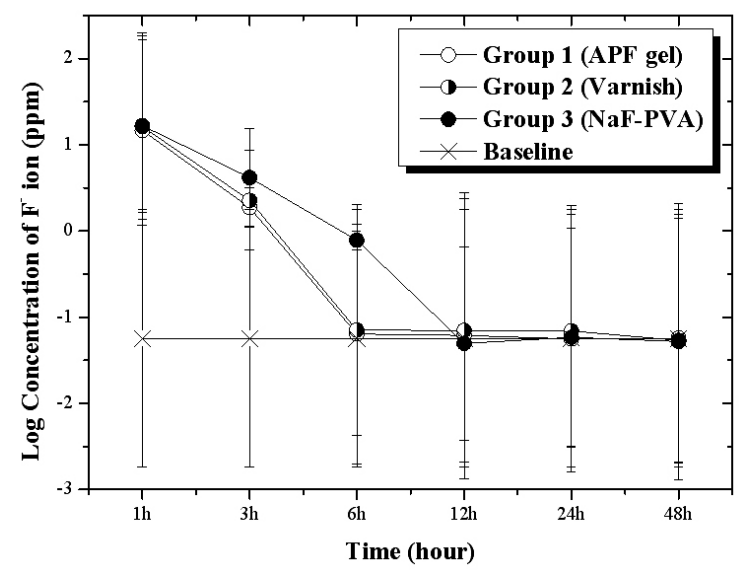

Fig. 4. Changes in the fluoride concentration of unstimulated whole saliva over time after application of different topical fluorides.

(A) The graph of time versus the fluoride concentration value. (B) The graph of time versus log-transformed value of the fluoride concentration. After 6 hours, group 3 showed significantly higher fluoride concentration than the baseline $(p<0.05)$ and also showed significantly higher value for fluoride concentration than group 1 and group 2.

차이를 보였다 $(p<0.05)$. 도포 후 6 시간에서는 1 군과 2 군 사 이의 유의한 차이는 없었으며 $(p>0.05), 1$ 군과 3 군, 2 군과 3 군 사이에서 유의한 차이를 보였다 $(p<0.05)$ (Table 4$)$.

\section{IV. 총괄 및 고찰}

불소의 치아우식증 예방 효과를 측정하기 위한 타액 내 불소 농도를 측정하는 방법으로 isotachophoresis ${ }^{11}$, ion chromatography ${ }^{12)}$, gas chromatography ${ }^{13)}$ 등 여러 가지 방법이 있는데 Frant와 Ross ${ }^{14)}$ 에 의해 개발된 불소이온전극을 이용하 는 방법이 그 간편성과 정확성에 의해 널리 사용되고 있다 ${ }^{15,16)}$. 비록 불소이온전극이 수산화 이온 이외에는 직접적인 간섭이 없긴 하지만 농도 자체에 반응하는 것이 아니라 활동도에 대해 반응하기 때문에 전체적인 이온세기를 맞추고 완충시켜주어야 한다 ${ }^{14)}$.

타액에서 불소는 두 가지 형태로 존재할 수 있다. 즉 이온형 태 외에 중성 $\mathrm{pH}$ 에서 타액 내 미생물과 상피세포, 유기물 등과 같은 성분이 불소와 결합할 수 있다 ${ }^{17-19)}$. 결합 형태로 존재하는 불소는 산이나 킬레이트제에 의해 쉽게 이온화될 수 있다 ${ }^{20)}$. 일 반적으로 불소이온전극의 측정한계는 $10^{-6} \mathrm{M}(0.02 \mathrm{ppm})$ 정도 이기 때문에 이보다 높은 농도로 농축시키는 것은 타액 내 불소 농도를 측정하는 데 정확성을 높여준닥. 본 연구에서도 타액 내 평균 불소 농도와 같이 비교적 낮은 불소 농도를 측정하기 위해 수집한 타액을 10 배 희석하여 불소이온전극과 불소이온측 정기를 이용하여 타액 내 불소농도를 측정하였다.

외인성 불소가 구강 내에 적용된 후 일시적으로 불소농도가 상승되고 점차 감소하는 과정을 oral fluoride clearance라고 한다 ${ }^{21}$. 이는 도포한 불소제제의 농도, 도포 후 지난 시간, 도포 방법, 불소의 잔류량에 영향을 줄 수 있는 구강 내 요소 등과 관 련이 있다 ${ }^{22.23)}$. 그 외로 분비되는 새로운 타액에 의해 희석되기
도 하고 삼키기도 하면서 계속적으로 농도 감소가 이루어진다. 고농도의 불소 적용 시 지연된 감소를 보이는 것은 불소가 구강 내 어딘가에 저장이 되며 이것이 서서히 방출됨을 의미한다리. 불소의 저장고는 법랑질이나 치태일 수 있으며 혀나 뺨 같은 연 조직이 될 수도 있다 ${ }^{7}$. 본 실험에서도 세 종류의 불소제제 적용 후 초기 1 시간과 3 시간 사이에 타액 내 불소농도의 큰 감소율 을 보였으며, 그 이후부터는 지연된 감소를 보이다가 12 시간 부터 48시간까지는 0,052 0.070 ppm으로 세 군이 모두 비 슷한 농도로 측정되었다.

국소적 불소제제 도포 후 타액 내 불소농도에 대한 문헌들을 살펴보면, Zhang 등 ${ }^{24)}$ 은 불소바니쉬 도포 후 6시간까지 초기 농도보다 높은 불소농도를 보였고 불소양치액을 적용했을 때보 다 더 오랫동안 불소농도가 유지되었다고 하였다. APF gel의 경우 박 등 25$)$ 은 $1.23 \%$ 산성불화인삼염 겔 도포 후 6 시간까지 대조군보다 유의하게 높은 불소농도를 보였다고 보고하였으며, Zero 등 ${ }^{26)}$ 은 $1.1 \%$ 불화나트륨 겔을 도포하고 타액 내 불소농 도를 조사하였는데 6시간 후 초기농도로 돌아왔다고 하였다. 불소테이프의 경우 2009년에 박 등 ${ }^{27}$ 의 연구에서 개발한 SCMC-T-5 불소테이프와 산성불화인삼염 겔, 불소바니쉬를 각각 적용 후 타액 내 불소농도를 비교한 연구 결과를 살펴보 면, 구강 내에서 도포 후 7시간까지 타액 내에서 높은 불소농도 를 보였으며, 이는 산성불화인삼염 겔과는 유사한 정도이고 불 소바니쉬 보다는 낮은 농도였다고 보고하였다. 본 연구에서는 불소제제 도포 후 3 시간이 지난 시점에서 타액 내 불소농도는 1 군은 $1.880 \mathrm{ppm}, 2$ 군은 $2.279 \mathrm{ppm}$, 그리고 3 군의 경우 $4.180 \mathrm{ppm}$ 이었다. 3군에서 세 그룹 중 가장 높은 농도를 보였 으며 이는 불소제제 도포 전 농도보다 통계학적으로 유의하게 높은 농도였다. 게다가 3 군의 경우 도포 후 6 시간의 농도는 $0.780 \mathrm{ppm}$ 으로 이 역시 불소제제 도포 전 농도보다 통계학적 으로 유의하게 높은 농도였다. Ritwik 등 ${ }^{28)}$ 은 $5 \%$ 불화나트륨 
을 함유하는 네 종류의 불소바니쉬인 Premier Enamel ProVarnish (EP) Colgate PreviDent (CP), Omni Vanish (OV), Omni VanishXT (OVXT)를 각각 발거된 치아에 적용 하였고 인공타액에 담근 후 불소 방출량을 48 시간 동안 측정하 였다. 그 결과 $\mathrm{CP}, \mathrm{EP}, \mathrm{OV}$ 는 도포 후 4시간 동안에서 최대 방 출량을 보였고 그 이후 낮은 농도를 유지하였으며, 반면에 OVXT는 불소방출량에 있어서 특이적인 변화가 없었다. 이를 통해 같은 $5 \%$ 불화나트륨을 함유하는 불소바니쉬 임에도 불구 하고 각각 다른 불소 방출량을 보임을 확인할 수 있었다. 본 연 구에서도 $5 \%$ 불화나트륨을 함유하는 불소바니쉬는 도포 후 첫 세 시간동안에 높은 불소방출량을 보이다가 그 이후부터는 타 액 내에서 낮은 불소 농도를 보였다.

타액분비율과 타액 내 불소 이온 농도는 밀접한 관련이 있기 때문에 현재 타액 분비에 영향을 미칠 수 있는 전신 질환이 없 고, 지난 6 개월 동안 타액 분비에 영향을 준다고 알려진 약물을 복용한 사람, 비자극성 타액분비율이 분당 $0.1 \mathrm{~mL}$ 이하인 경 우는 연구대상에서 제외하였다. 연구 전 측정한 비자극성 타액 분비율은 1 군 $(0.817 \pm 0.321 \mathrm{~mL} / \mathrm{min}), 2$ 군 $(0.803 \pm$ $0.426 \mathrm{~mL} / \mathrm{min}) 3$ 군 $(0.933 \pm 0.392 \mathrm{~mL} / \mathrm{min})$ 모두 일반적 으로 알려진 정상인의 평균 비자극성 타액분비율 $(0.3 \sim 0.4$ $\mathrm{mL} / \mathrm{min}$ )과 비교할 때 ${ }^{29}$, 약간 증가된 수치를 보였으나 세 군 간 유의한 차이는 없었다.

불소의 전신적 부작용은 소량을 장기간 섭취함에 의해 유발 되는 만성 부작용과 과량을 일시에 섭취함에 의해 유발되는 급 성 부작용으로 나눌 수 있는데, 불소 국소도포를 위해 임상에서 사용되는 불소 화합물은 모두 고농도의 불소를 함유하고 있으 므로 부주의한 연하 시에는 이러한 급성 부작용의 가능성이 있 당. 불소의 전신적 섭취를 줄이기 위한 방법으로 불소제제의 물리적 형태를 변화시키는 방법이 시도되어져 왔는데, 본 연구 실에는 불소를 함유한 고분자 접착 테이프를 개발해왔다.

$\mathrm{PVA}$ 는 합성고분자의 일종이면서 물에 녹는 독특한 성질을 가지고 있다. $\mathrm{PVA}$ 는 탄소 $(\mathrm{C})$, 수소 $(\mathrm{H})$, 산소 $(\mathrm{O})$ 로 된 합성수 지이며, 염소 $(\mathrm{Cl})$, 질소 $(\mathrm{N})$, 황 $(\mathrm{S})$ 등의 성분은 포함되어 있지 않아 극히 유해성이 낮은 재료이다. PVA는 또한 높은 인장강 도, 압축강도, 내마모성, 유연성 등의 뛰어난 역학적 성질을 지 니고, 용해도와 내화학성이 우수하여 다른 고분자와 잘 혼화되 므로 그 응용범위가 매우 광범위하며 인체장기 대체용 하이드 로겔, 약물전달시스템(Drug Delivery System, DDS), 항암 제, 생체센서(biosensor), 지혈제, 생체반응기(bioreactor) 등 의료용 재료로 널리 적용되고 있다 ${ }^{31-33)}$. 본 저자가 포함된 연구 팀이 개발한 불소를 함유한 고분자 접착 테이프는 무색투명하 여 심미적이고, 불쾌한 맛이 없으며 표면이 매끈하여 끈적거리 는 느낌이 없다. 또한 구강 내 도포 시 치면을 건조시킬 필요가 없어 시술과정이 간편하다.

이번 연구에서 상악 우측 제 1 대구치에서부터 상악 좌측 제 1 대구치의 12 개의 치아에 적용된 불소겔 $1 \mathrm{~mL}$ 에는 $12.3 \mathrm{mg}$ 의 불소를 포함하며 불소바니쉬 $0.3 \mathrm{~mL}$ 안에는 $6.79 \mathrm{mg}$ 의 불소 를 함유하고 있다. 또한 동일한 부위에 적용한 NaF-PVA 테이
프 $1 \times 12 \mathrm{~cm}$ 크기의 불소테이프 속에는 $1.18 \mathrm{mg}$ 의 불소가 포 함되어 있는데 이는 현재 시판 중인 불소겔과 불소바니쉬의 불 소 함량에 비해 적은 양임에도 불구하고, 불소제제 도포 후 타 액 내 불소농도를 측정하였을 때 6시간 후에서 불소겔과 불소 바니쉬의 타액 내 불소농도와 비교 시 유의한 차이를 보여주었 다. 이를 통해 NaF-PVA 테이프는 불소겔과 불소바니쉬에 비 해 구강 내 잔류되어 섭취되는 양이 적고 치면에 잘 붙어 유지되 기 때문에 좀 더 지속적으로 불소를 유리할 수 있다고 생각된다.

최근 김 등 ${ }^{34}$ 에 의하여 $\mathrm{NaF}-\mathrm{PVA}$ 테이프의 치아우식증 예방 효과에 대하여 in vitro 연구가 이루어졌다. 소의 절치를 사용 하여 제작한 표본에 $\mathrm{NaF}-\mathrm{PVA}$ 테이프와 불소바니쉬, $\mathrm{CPP}-$ ACP (Casein Phosphopeptide-Amorphous Calcuim Phosphate) 제제를 적용 후 $\mathrm{pH}$-cycling 과정을 거친 후 주사 전자현미경 하에서 법랑질 표면을 관찰하여 법랑질 탈회에 미 치는 영향을 분석하였다. 그 결과 NaF-PVA 테이프의 법랑질 탈회 억제 효과는 $\mathrm{CPP}-\mathrm{ACP}$ 제제보다 우수하며, 불소바니쉬의 효과와 유사하다고 보고하였다. 본 연구를 통해 NaF-PVA 테 이프가 불소바니쉬 보다 좀 더 지속적으로 불소를 유리함을 확 인하였는데, 이는 김 등의 in vitro 연구에서 $\mathrm{NaF}-\mathrm{PVA}$ 테이프 의 우수한 법랑질 탈회 억제 효과와 상응하는 결과라고 볼 수 있다.

이번에 개발된 불소 테이프는 기본적으로 PVA의 추가적인 화학적 개질을 시도하지 않은 시제품이지만, 추후 화학적으로 여러 방식의 개질이 가능한 재료이다. 가교반응을 통해 구강 내 에서 녹는 시간 및 온도를 조절할 수 있으며, 기계적인 물성의 개선이 가능하다. 또한 테이프의 두께 조절과 테이프에 포함되 는 불소의 함량을 증가시키는 등의 방법으로 불소 테이프의 성 질을 개선한다면 구강 내 잔류되는 불소량을 더욱 증가시킬 수 있다. 이와 같은 테이프의 우수한 물리화학적 특성과 적용의 용 이함으로 인해 치아우식증의 예방을 위한 새로운 불소전달시스 템으로써의 역할을 기대할 수 있을 것으로 사료된다.

\section{V. 결 론}

이 연구는 PVA 기저재에 불화나트륨을 분사하여 제작한 고 분자 접착 테이프 $(\mathrm{NaF}-\mathrm{PVA})$ 의 불소 유리 능력을 평가하기 위 하여 시행되었다. 피실험자의 구강 내에 불소제제로 불소겔, 불 소바니쉬, NaF-PVA 테이프을 도포하여 1시간, 3시간, 6시간, 12 시간, 24 시간, 48 시간 경과 후 타액 내 불소농도를 원심분리 방법과 불소이온전극을 이용하여 평가한 결과 다음과 같은 결 론을 얻었다.

도포 후 3 시간까지 세 군 모두 불소제제 도포 전 농도보다 유 의하게 높은 불소농도를 보였으며, 3 군의 경우 도포 후 6 시간 에서도 불소제제 도포 전 농도보다 유의하게 높은 불소농도를 보였다 $(p<0.05)$.

도포 후 6 시간에서 3 군은 1 군과 2 군보다 유의하게 높은 불소 농도를 보였고 $(p<0.05), 1$ 군과 2 군 사이의 유의한 차이는 없 었다 $(p>0.05)$. 
이상의 결과를 종합하여 보면 $\mathrm{NaF}-\mathrm{PVA}$ 테이프는 불소겔과 불소바니쉬에 비해 낮은 불소량을 함유하지만, 치면과의 접착 이 유지되어 좀 더 지속적으로 구강 내에서 불소를 유리하는 능 력을 보인다고 할 수 있다. 향후 $\mathrm{NaF}-\mathrm{PVA}$ 테이프의 두께와 불소 함량을 조정하고 구강 내에서 용해되는 시간을 지연시키 기 위한 추가적인 연구를 시행한다면 불소방출량이 향상된 보 다 우수한 치아우식증 예방 제제로 개발이 가능할 것이다.

\section{References}

1. Hellwig E, Lennon AM : Systemic versus topical fluoride. Caries Res, 38:258-262, 2004.

2. White DJ, Nelson DGA, Faller RV : Mode of action of fluoride: application of new techniques and test methods to the examination of the mechanism of action of topical fluoride. Advances in Dental Research, 8:166-174, 1994.

3. Øgaard B, Seppä L, Rolla G: Professional topical fluoride applications -clinical efficacy and mechanism of action. Advances in Dental Research, 8:190-201, 1994.

4. Fejerskov O, Thylstrup A, Larsen MJ : Rational use of fluorides in caries prevention. A concept based on possible cariostatic mechanism. Acta Odontol Scand, 39:241-249, 1981.

5. Ten Cate JM : In vitro studies on the effects of fluoride on $\mathrm{de}^{-}$and remineralization. $J$ Dent Res, 69:614-619, 1990

6. Margolis HC, Moreno EC : Physiochemical perspectives on the cariostatic mechanism of systemic and topical fluorides. J Dent Res, 69:606-613, 1990.

7. Zero DT, Raubertas RF, Featherstone JD, et al. : Fluoride concentrations in plaque, whole saliva, and ductal saliva after application of home-use topical fluorides. J Dent Res, 71:1768-1775, 1992.

8. Adair SM : Current fluoride therapy in dentistry for children. Current Opinion Dent, 1: 583-591, 1991.

9. Toumba KJ, Curzon ME : A clinical trial of a slowreleasing fluoride device on children. Caries Res, 39:195-200, 2005.

10. Marini I, Cecchi L, Vecchiet F, Spiazzi L : Intraoral fluoride releasing device: a new clinical therapy for dentine sensitivity. J Periodontol, 71:90-95, 2000.

11. Zero DT, Fu J, Espeland MA, Featherstone JD : Comparison of fluoride concentrations in unstimulated whole saliva following use of a fluoride dentifrice and a fluoride rinse. J Dent Res, 67:1257-1262, 1988.
12. Lindahl CB : Fluoride and monofluorophosphate analysis. Caries Res, 17:9-20, 1983.

13. Retief DH, Summerlin DJ, Harris BE, Bradley EL : An evaluation of three procedures for fluoride analysis. Caries Res, 19:248-254, 1985.

14. Front MS, Ross JW jr : Use of total ionic strength adjustment buffer for electrode determination of fluoride in water supplies. Anal Chem, 40:1169-1171, 1968.

15. Edelstein BL, Cottrel D, O'sullivan D, Tinanoff N : Comparison of colorimeter and electrode analysis of water fluoride. Pediatr Dent, 14:47-49, 1992.

16. Weinberger SJ, Johnston DW, Wright GZ : A comparison of two systems for measuring water fluoride ion level. Clin Prev Dent, 11:19-22, 1989.

17. Taves DR : Evidence that there are two forms of fluoride in human serum. Nature, 217:1050-1051, 1968.

18. Taves DR : Comparison of organic fluoride in human and nonhuman serum. J Dent Res, 50:783, 1971.

19. Jenkins GN, Edgar WM : Distribution and forms of fluoride in saliva and plaque. Caries Res, 11:226242, 1977.

20. Fry BW, Taves DR : Serum fluoride analysis with the fluoride electrode. J Lab Clin Med, 75:1020$1025,1970$.

21. Dawes C, Weatherell JA : Kinetics of fluoride in the oral fluids. J Dent Res, 69:638-644, 1990.

22. Sjögren K : How to improve oral fluoride retention? Caries Res, 35:14-17, 2001.

23. Heath K, Singh V, Logan R, Mclntyre J : Analysis of fluoride levels retained intraorally or ingested following routine vlinival applications of topical fluoride products. Aust Den J, 46:24-31, 2001.

24. Zhang XF, Chen X, Pan L : Fluoride concentration in saliva after use of fluoride varnish. Shanghai Kou Qiang Yi Xue, 12:241-243, 2003.

25. Park SJ, Kim HD, Kim CC : A study of the change of salivary fluoride concentration with time after various topical fluoride treatments. $J$ korean Acad Pediatr Dent, 26:262-274, 1999.

26. Zero DT, Raubertas J, Fu AM : Studies of Fluoride retention by oral soft tissues after the application of home-use topical fluorides. J Dent Res, 71:15461552, 1992.

27. Park SH, Lee SH, Lee NY : A change of the salivary fluoride concentration after fluoride-containing tape application. J korean Acad Pediatr Dent, 36:377- 
383, 2009.

28. Ritwik P, Aubel JD, Hagan J, et al. : Evaluation of short-term fluoride release from fluoride varnishes. $J$ Clin Pediatr Dent, 36:275-278, 2012.

29. Sreebny LM : Xerostomia: diagnosis, management and clinical complications. 2nd edition. British Dental Association London, 43-46, 1996.

30. Newbrun E : Topical fluoride therapy : Discussion of some aspects of toxicology, safety and efficacy. $J$ Dent Res, 67:114, 1988.

31. C.A Finch : Poly(vinyl alcohol), 2nd edition. NewYork Wiley, 1992.
32. Shafee EE, Naguib HF : Water sorption in crosslinked poly(vinyl alcohol) networks. Polymer, 44:1647-1653, 2003.

33. Korsmeyer RW, Peppas NA : Effect of the morphology of hydrophilic polymeric matrices on the diffusion and release of water soluble drugs. J Membr Sci, 9:211-227, 1981.

34. Kim MJ, Lee SH, Lee NY, Lee IH : Evaluation of the effect of PVA tape supplemented with $2.26 \%$ fluoride on enamel demineralization using microhardness assessment and scanning electron microscopy: In vitro study. Arch Oral Biol, 58:160-166, 2013. 
국문초록

\title{
폴리비닐알코올 기반 고분자 불소 함유 테이프의 구강 내 불소 유리 성능 평가
}

\author{
이가영 · 이상호 · 이난영
}

\section{조선대학교 치의학전문대학원 소아치과학교실}

연구의 목적은 인체 안정성이 입증된 고분자제제인 폴리비닐알코올(PVA, polyvinyl alcohol)로 얇은 박막을 제조하고 불 화나트륨 $(\mathrm{NaF})$ 을 첨가하여 불소를 함유한 고분자 접착 테이프 $(\mathrm{NaF}-\mathrm{PVA})$ 를 개발하여 피실험자의 구강 내에 도포 후 잔류 하는 불소농도를 측정하였다. 이를 통해 제제 도포 전후의 타액 내 불소농도를 분석하여 불소를 함유한 고분자 접착 테이프 의 치아우식증 예방효과를 간접적으로 평가하였다. 불소겔(60seconds taste ${ }^{\circledR}$, Group 1), 불소바니쉬(FluoroDose ${ }^{\circledR}$ var- $^{-}$ nish, Group 2)와 불소를 함유한 고분자 접착 테이프(NaF-PVA, Tiral product, Group 3)를 각각 15명씩 상악 치아 12 개의 순면에 도포 후, 1 시간, 3 시간, 6 시간, 12 시간, 24 시간, 48 시간 후 비자극성 타액 내 불소농도를 불소이온전극을 이용 하여 측정하였다.

도포 후 3 시간까지 세 군 모두 불소제제 도포 전 농도보다 유의하게 높은 불소농도를 보였으며 3군의 경우 도포 후 6시간 에서도 불소제제 도포 전 농도보다 유의하게 높은 불소농도를 보였다 $(p<0.05)$.

도포 후 6 시간에서 3 군은 1 군과 2 군보다 유의하게 높은 불소농도를 보였고 $(p<0.05), 1$ 군과 2 군 사이의 유의한 차이는 없었다 $(p>0.05)$.

주요어: 불소 테이프, 불소 이온 농도, 폴리비닐알코올 